\title{
God, Incarnation, and Metaphysics in Hegel's Philosophy of Religion
}

\author{
Paolo Diego Bubbio \\ University of Sydney
}

Article-draft, April 17, 2012. Please do not quote without permissions.

Comments are warmly welcome: paolodiego.bubbio@sydney.edu.au

\begin{abstract}
In this paper, I draw upon the 'post-Kantian' reading of Hegel to examine the consequences Hegel's idea of God has for understanding his metaphysics. In particular, I apply Hegel's 'recognition-theoretic' approach to his theology. Within the context of this analysis, I focus especially on the incarnation and sacrifice of Christ.

First, I claim that Hegel's philosophy of religion employs a peculiar notion of sacrifice (kenotic sacrifice). Here, sacrifice is conceived as a withdrawal, that is, as a 'making room' for the other. Second, I argue that the idea of kenotic sacrifice plays a fundamental role in Hegel's account of Christ. Third, I conclude by sketching some of the consequences Hegel's idea of a God who renounces his own divinity has for an idealistically conceived metaphysics. My main thesis is that Hegel's turn to Christianity can be regarded as indicative of his endorsement of social and political freedoms that are characteristic of modernity. That is, modern freedoms are cognate with a certain idea of God. Thus, the notion of incarnation is conceived as the expression of a spirit that advances only insofar as it is willing to withdraw and make room for the other.
\end{abstract}

\section{Introduction}

Hegel scholarship in the Anglophone world has recently witnessed the establishment of new approaches that aim to show the relevance and topicality of a thought that, for a long time, was often considered one of the most abstract, or even lunatic, instances 
of a philosophical school (Idealism) that was often regarded as incapable of offering any significant contribution to contemporary thought. One of these new approaches is represented by the so-called 'post-Kantian' interpretation of Hegel pioneered by Robert Pippin and Terry Pinkard. ${ }^{\mathrm{i}}$ At the core of this interpretation is the idea that Hegel's philosophy does not represent a regression to pre-Kantian metaphysics, but rather an extension of Kant's critical philosophy. While such an approach might lead to the conclusion that Hegel's philosophical project is substantially anti-metaphysical, it has been suggested that it is possible to regard Hegel's thought in continuation with the Kantian project and, at the same time, to still consider Hegel's philosophy as maintaining a metaphysical dimension — or, better, as proposing a different kind of metaphysics: an idealist metaphysics.

To understand how this interpretation is possible, one has to consider that Kant's use of the term 'metaphysics' was ambiguous. Traditionally, the Critique of Pure Reason has been interpreted as representing a radical scepticism about metaphysics. Metaphysics is 'the science of illusion' because it has the intention of providing knowledge about objects (such as the soul, or God), of which, no empirical (i.e., spatio-temporal) intuitions are possible. There is no doubt that most of the Critique of Pure Reason pursues this path. Sometimes, however, Kant seems to suggest that metaphysics is somehow possible — not the traditional (pre-Kantian) metaphysics that treated metaphysical objects as if they were natural objects, but a new (idealist) metaphysics, conceived as that discipline in which reason is concerned with its own products. ${ }^{\text {iii }}$ The possibility of reading Kant's account of metaphysics in two different ways has been suggested by Sebastian Gardner (who distinguishes between an "analytic" and an "idealist" way of interpreting the Critique of Pure Reason) ${ }^{\mathrm{iv}}$. This interpretation was articulated more fully by Paul Redding (who calls the two viewpoints 'weak transcendental idealism' and 'strong transcendental idealism', respectively). ${ }^{\mathrm{V}}$ A meaningful example is represented by the ideas of the human soul and of God. Whereas pre-Kantian metaphysics dealt with the human soul and God as if they were natural objects, Kant approached them as products of reasons that hold a peculiar regulative status, that is, as regulative principles that 'serve to lead the understanding by means of reason in regard to experience and to the use of its rules in the greatest perfection' ${ }^{\text {vi }}$ In other words, in light of Kant's 'strong transcendental idealism', the existence of the objects of metaphysics is different from the existence 
of natural objects - that is, metaphysical objects have an ideal rather than a 'naturalistic' existence.

If this is the case, then it is possible to read Hegel's thought as a development of Kant's critical philosophy and in continuity with his project-or at least with one of the possible interpretations of his project, one that Kant himself advanced: 'strong transcendental idealism'. 'Read as an "absolute" idealist in a post-Kantian sense', Redding writes, 'Hegel might be seen as extending such a non-realist approach to both the individual soul and to God' ${ }^{\text {vii }}$ In other words, Hegel is regarded as conceiving of the content of metaphysics as entirely normative rather than as a type of 'scientific' or 'naturalistic' knowledge about the way the world is 'anyway'. From this point of view, Hegel's idealist metaphysics should be conceived as that 'realm of reason' whose objects (e.g., values and norms) exist qua products of reason. Clearly, a problematic aspect of such an approach might be represented by the question of what criterion should be used to determine which objects belong or do not belong to that 'realm of reason'. Hegel's answer to this question is forged out of an assimilation of the Kantian conception that ideas play a regulative and normative role in human cognition and morality in conjunction with the Fichtean concept of recognition (Anerkennung). The main idea here is that to be an idealist about metaphysical objects is to recognize that their reality (their existence as objects of reason) is conditional upon human recognition. Thus, for example, to be an idealist about God means to claim that God exists (qua metaphysical object, i.e., as a product of reason) insofar as we recognise him as existing. Furthermore, from a Hegelian perspective, human beings themselves have to be regarded as products of reason. Human beings, qua knowing subjects, exist in the realm of reason only in as much as they mutually recognize themselves as existing. ${ }^{\text {viii }}$ In other words, Hegel is thought of as making the necessary reflexivity of self-consciousness dependent on one's recognition of other subjects as self-conscious subjects. As Redding nicely puts it, 'Without this system of recognition, there is no self, just a natural organism' ${ }^{\text {ix }}$

Because the (ideal) existence of metaphysical objects is dependent on recognition, it follows that recognition is the 'organising principle' of that realm of reason in which Hegelian metaphysics consists. As already mentioned, the fundamental act of recognition is the recognition of the other. If I, as a subject (or, to use Hegel's terminology, as a subjective spirit), do not recognise others as human beings (and, as 
such, equally capable to recognise me as a human being), the very possibility of a realm of reason made up by values and norms (whose existence depends upon a joint act of recognition) disappears. In fact, if metaphysical objects exist only insofar as human subjects recognise them as existing, and if the existence of human beings (as distinct from mere natural organisms) is, in turn, dependent upon mutual recognition, it follows that recognition of the other is the fundamental organising principle of Hegel's metaphysics.

While the importance of recognition is often acknowledged with respect to Hegel's subjective and objective spirit (especially his political and moral philosophy), ${ }^{\mathrm{x}}$ its relevance for absolute Spirit (Hegel's metaphysics) has still to be shown in all its clarity. As a part of this larger project, this paper aims to show the importance of recognition in Hegel's philosophy of religion ${ }^{x i}$ (the second moment of Hegel's absolute spirit), an area that is often appealed to when criticising the post-Kantian interpretation of Hegel. More specifically, the main focus of the paper is an analysis of the notion of kenotic sacrifice. I claim that an understanding of kenotic sacrifice is essential to fully grasping the relevance of recognition and what it entails (Section 1). Furthermore, I suggest that once the kenotic aspect of the Hegelian notion of sacrifice has been made clear, it becomes easier to explain the emphasis that Hegel places on the incarnation of Christ (Section 2). Finally, I claim that Hegel's particular view of kenotic sacrifice, conceived as the key element of Christ's incarnation, sheds light on how his metaphysics is to be interpreted, and I claim that the organising principle of an idealist metaphysics is the reciprocal recognition of different finite points of view. The conclusion will also provide a possible solution to the dispute between 'left Hegelians' and 'right Hegelians' concerning the status of the idea of God in Hegel's philosophy.

\section{Sacrifice, Kenosis, and Recognition}

There is little or no evidence in previous literature of a connection between recognition and sacrifice. This is partly because the interpretative standpoint that emphasises the importance of recognition for Hegel's philosophy has not yet addressed Hegel's philosophy of religion. This lack is probably also due to the influence of Georges Bataille's essay 'Hegel, la Mort et le Sacrifice'. xii Bataille sees 
sacrifice merely as destruction or suppression. However, I claim that this is only one aspect of the Hegelian conception of sacrifice. There is another, and even more important, aspect. It is the kenotic sacrifice, or sacrifice as withdrawal.

To contextualise this distinction, it is useful to turn to the section of Hegel's 1827 Lectures on the Philosophy of Religion devoted to the Cultus. Here, Hegel distinguishes three forms of the Cultus: devotion (Andacht), external sacrifice (Opfer), and interiorised sacrifice. ${ }^{\text {xii }}$ Introducing the second form (external sacrifice), Hegel writes:

Negation exists within devotion and even maintains an outward configuration by means of sacrifice. The subject renounces something or negates something in relation to itself. It has possessions and divests itself of them in order to demonstrate that it is in earnest. On the one hand this negation is accomplished in a more intensive fashion only through the sacrificing or burning of something - even through human sacrifice; on the other hand the sensible enjoyment [of the sacrifice], for instance the eating and drinking, is itself the negation of external things. Thus from this negation or from the sacrifice one advances to enjoyment, to consciousness of having posited oneself in unity with God by means of it. The sensible enjoyment is linked directly with what is higher, with consciousness of the linkage with God. (LPR 194)

This account of external sacrifice substantially mirrors the picture of the 'sacrificial dedication' (Hingabe) that is featured in the Phenomenology, but in the Lectures the fundamental characteristics of this form of sacrifice are stressed more explicitly. Sacrifice appears when negation enters into the act of devotion, and it consists in the suppression, or negation, of something external to the subject. The enjoyment resulting from this sacrifice is an expression of a reestablishment of the unity between nature and spirit. This form of sacrifice is external and is never interiorised, not even when performed on the subject itself, as happens, for example, in acts of selfmortification, in which sacrifice as suppression remains, as Hegel writes later in the Lectures, 'the abstractly negative' (LPR 300). A further confirmation of this reading comes from Hegel's analysis of the myth of Prometheus. In Greek mythology, Prometheus is regarded as the one who taught humans to perform sacrifices. When he sacrificed to Zeus for the first time, he presented two sacrificial offerings, one consisting of beef hidden inside an ox's stomach, and the other consisting of bones 
wrapped in 'glistening fat'. The god was caught in the snare and chose the latter, thus establishing the usual procedure for future sacrifices, where humans keep the meat to be eaten and burn the bones as a sacrificial offering. Prometheus, Hegel remarks, 'still belongs among the Titans', that is, pre-human creatures, 'for the very reason that these skills are only to satisfy the human needs - they have no ethical authority, they are not laws' (LPR 338). External sacrifice always turns out to be "utilitarian" destruction or suppression of something for the sake of something else, be it the satisfaction of needs, the benevolence of the gods, or a simple manifestation of power. ${ }^{\text {xiv }}$

External sacrifice is not, however, the highest form of the cult. The third and highest form is represented by the interiorised sacrifice, whereby one not only destroys external things but also gives up one's own subjectivity. Hegel writes:

The third and highest form within the cultus is when one lays aside one's own subjectivity - not only practices renunciation in external things such as possessions, but offers one's heart or inmost self to God and senses remorse and repentance in this inmost self; then one is conscious of one's own immediate natural state (which subsists in the passions and intentions of particularity), so that one dismisses these things, purifies one's heart, and through this purification of one's heart raises oneself up to the realm of the purely spiritual. This experience of nothingness can be a bare condition or single experience, or it can be thoroughly elaborated [in one's life]. If heart and will are earnestly and thoroughly cultivated for the universal and the true, then there is present what appears as ethical life. To that extent ethical life is the most genuine cultus. But consciousness of the true, of the divine, of God, must be directly bound up with it. (LPR 194)

What happens when sacrifice is interiorised? First, sacrifice becomes self-sacrifice (Aufopferung), not in the form of self-suppression or self-mortification, but as an offering of the 'inmost self'. When one 'lays aside one's own subjectivity', she senses 'remorse and repentance'. As we know from The Philosophy of Right, subjectivity is, for Hegel, 'a one-sided form' and 'pure certitude of itself in contrast with the truth' (PR §25): it is a (false) presumption of objectivity. ${ }^{\mathrm{xv}}$ In the previous state, there was no distinction between subjectivity and objectivity: in the external sacrifice, the relation with the divine is immediate, and the subject is concerned only with his purported achievement (satisfaction of needs, gods' benevolence, etc.). ${ }^{\text {xvi }}$ Once the 
subject has given up her own subjectivity, she becomes conscious of her finiteness (her 'nothingness' in relation to the divine) and dismisses her passions and intentions. If this is not a one-time experience, but a recurring and cultivated habit, then it becomes the condition for the emergence of a proper ethical life, and the foundation of metaphysical knowledge ('consciousness of the true, of the divine, of God').

The interiorised sacrifice has, therefore, several implications for Hegel's conception of metaphysics, some of which will be sketched in the final section. For now, I would like to stress that the main distinction between external sacrifice and interiorised sacrifice consists in this: external sacrifice is suppressive ('the abstractly negative'); conversely, interiorised sacrifice is kenotic. The term 'kenotic' derives from the Greek word kenosis, meaning 'emptiness' xvii The use of the term in connection with a 'sacrificial' dynamic (but different from the traditional 'suppressive' meaning of sacrifice) dates back to the Christian New Testament, in particular Philippians 2:7, where, to describe the incarnation of Christ, it is said that Christ 'withdrew' or 'emptied himself' (ekenosen). In the previous verse (Philippians 2:6), it is written that Christ did not consider his divine form (morphe) as something 'to be grasped' or 'to be kept', but was willing to 'empty' or 'annul' himself to assume a different 'form'. What is implied is that God gave up those divine privileges that are incompatible with the finite nature of a human being (omnipotence, omnipresence, omniscience, etc.) to become fully human. Retrospectively, and through a connection with the Jewish Kabbalistic notion of tsimtsum, ${ }^{\text {xvii }}$ the term kenosis has also been used by some theologians to describe God's original act of creation: God created the universe by voluntarily limiting his divine infinity, by withdrawing, and making room for the universe and finite beings. ${ }^{\text {xix }}$ The notion of kenotic sacrifice plays a minor and often hidden, but nonetheless significant, role in medieval and early-modern philosophy and theology. The first thinker to model a theological conception on the notion of kenosis was the German philosopher and mystic Meister Eckhart. ${ }^{\mathrm{xx}}$ Eckhart was a seminal figure, and through the work of his disciples (among them John Tauler and Henry Suso), his doctrines had a significant impact on Martin Luther and the Reformation.

Eckhart's conception of kenosis resurfaced in the thought of the seventeenth century mystical thinker Jacob Böhme. Significantly, Böhme is one of the two figures (the other being Francis Bacon) Hegel addresses in the section 'Modern Philosophy in 
its First Statement' of his Lectures on the History of Philosophy: it is 'through him', Hegel claims, 'that philosophy of a distinctive character first emerged in Germany' (LHP 95). ${ }^{x x i}$ What distinguishes Böhme's conception of kenosis from previous accounts (such as Eckhart's) is that while the process of kenosis for Eckhart was leaving God 'intact', without substantially affecting his divine prerogatives ${ }^{\text {xxii }}$, Böhme conceived of the kenotic process as an emptying that involves a change in the underlying substance' xxiii In short, Böhme's God can change and, most importantly, can suffer-and, in fact, does suffer.

It is a Böhmian conception of kenosis, I claim, that is at work in the interiorised sacrifice. The importance of the notion of kenosis in Hegel's thought, as well as Böhme's influence in this respect, has already been stressed in previous literature, most notably by O'Reagan in his The Heterodox Hegel. ${ }^{\text {xxiv }}$ Nevertheless, O'Reagan, consistently with his interpretative approach, contextualises the emphasis on kenosis within an analysis of the mystical features of Hegel's theology. Recognition does not appear to play a significant role in his account of Hegel's philosophy of religion (or absolute spirit broadly conceived), and O'Reagan apparently accepts the assumption that Hegel is a realist about God. Both of these elements prevent him from conceiving of the notion of kenosis as playing a major role in the Hegelian structure of relations between his philosophy of religion and his idealist metaphysics.

It has been said that the recognition of the other is the necessary pre-condition for the existence of that realm of reason in which Hegel's metaphysics consists. It is worth remembering that this realm of reason is not a Platonic 'world of ideas', ${ }^{\mathrm{xxv}}$ but the set of 'idealities' (which includes, but it is not limited to, values, norms, and beliefs) whose reality is conditional upon recognition. ${ }^{\text {xxvi }}$ Furthermore, as shown by the Hegelian passages analysed above, there cannot be a recognition of the other if the subject does not preliminarily renounces its own absoluteness, that is, its presumption of considering its subjectivity as absolute objectivity. Only if the subject withdraws and 'makes room', as it were, for the other's point of view (thus recognising itself as relative, i.e., as located historically, geographically, etc.), is the process of recognition, and with it the related establishment of a realm of reason, indeed possible.

Because the kenotic sacrifice is the representation of the act that effectively establishes the process of recognition, it is also the condition for the existence of self- 
consciousness. ${ }^{\text {xvii }}$ It has been said that human beings themselves must be regarded as products of reason. Therefore, our own identity (as human beings) is constituted through the process of withdrawing. ${ }^{\mathrm{xx} v i i i}$

This first section has aimed to show the limits of conceiving sacrifice only in its suppressive meaning. Conceiving sacrifice as suppression or 'abstract negation' does not allow to make sense of the interiorised or kenotic sacrifice and, therefore, cannot connect sacrifice and recognition. Conversely, the notion of kenotic sacrifice fits well with the post-Kantian reading, especially when it employs the recognition-theoretic approach as a means of making sense of Hegel's idealist metaphysics. Furthermore, once it is assumed that kenotic sacrifice plays an important role in Hegel's account of absolute spirit, it becomes easier to explain Hegel's interest in the incarnation and sacrifice of Christ. Therefore, the next section will be devoted to an analysis of the philosophical value of the incarnation of Christ in light of the outcomes that result from this reading.

\section{The Incarnation of Christ}

It is well known that in his youth Hegel shared with some of his contemporaries (such as Schelling and Hölderlin) an anti-Christian feeling and a 'pagan' orientation, showing enthusiasm for Greek mythology and gods. From the Phenomenology onwards, however, 'he had incorporated a more conventional Christian theological outlook, the significance of which was to remain disputed among his followers after his death'. ${ }^{x i x}$ This change is partly due to the development of a methodological approach that assumes that, to analyse a cultural subject (say, religion), it is a better philosophical strategy to start from existing beliefs and symbolic features rather than moving from an abstract ${ }^{\mathrm{xxx}}$ standpoint and, like Kant, speculating what religion should be. This attitude of speculation, in Hegel's view, can be associated with that of a Scholastic philosopher who declared that he will not go into the water 'until he has learned to swim' (LPR 95). Nevertheless, this methodological approach alone cannot explain either Hegel's idea that Christianity is the highest form of religion (the 'consummate' religion) or Hegel's increasing interest in the incarnation of Christ. In fact, these two elements are connected. One feature that the Greek gods have in common with the Jewish God (at least as it is presented in the Bible) is that they do 
not experience suffering as a human would. They feel (human) feelings, such as jealousy and anger, but they do not suffer, they do not die, and (perhaps most importantly) they do not fail. From this point of view, the Christian god is very different: it is a God who becomes fully human. ${ }^{x x x i}$ Therefore, it can be argued that Hegel regarded Christianity as the highest form of religion precisely because of its central image of God becoming man. But again, why is this image so important for Hegel?

Here, we should remember that Hegel is concerned with God as the subject of a philosophical analysis. In other words, his philosophy of religion is a philosophy of religion: ${ }^{\text {xxxii }}$ he is not interested in advancing a religious account, but analysing god qua object of human reason. Furthermore, Hegel is an idealist. Therefore, when he takes into consideration Christian doctrines, he is not concerned with their metaphysical correctness (as he would be if he were a metaphysical realist), but with their regulative and symbolic value. The centrality of the incarnation of Christ in Hegel's philosophy can be fully grasped, I claim, only if its function as model of the kenotic sacrifice is taken into consideration.

The figure of Jesus Christ in Hegel's philosophy clearly represents the incarnation of the divine and the overcoming of the abstract opposition between the divine and the human. This overcoming can be realised only through a sacrifice that consists in a withdrawal. Effectively, in becoming human, God sacrifices his own divinity and absoluteness and accepts all human limitations, including being geographically and historically located. Considered as such, the notion of incarnation is not only an early mythical expression of the dialectic that reveals the progressive incarnation of the spirit. It is also the symbolic and, as I will show, regulative expression, portrayed in the form of historical narrative, of a content conceptualised in philosophy. This content is the process of kenosis between self and other, which is essential for recognition. In fact, if recognition is, first and foremost, the subject's withdrawal and renunciation of its own 'objective' point of view, what can better symbolise this process than a god who becomes human and renounces the God's eye point of view?

The death of Christ is therefore the highest expression of this kenotic sacrifice, as it shows that God has indeed withdrawn from his absoluteness and has fully accepted human nature—he has accepted it until death. Hegel writes: "To sacrifice" means to sublate the natural, to sublate otherness. It is said: "Christ has died for all". This is not 
a single act but the eternal divine history: it is a moment in the nature of God himself: it has taken place in God himself" (LPR 470). The sacrifice of Christ is not merely 'a single act', but it shows that the Christian God is not an immutable, always already actualised being; conversely, he is a 'being in becoming. ${ }^{x x x i i i}$

Thus, Christ sublates 'the natural' by withdrawing from the 'supernatural', accepting the natural and overcoming it through his kenotic sacrifice. This overcoming is what Christ's followers are required to remember in the Eucharist. Furthermore, the representation of the Christian God in the internalized mode of memory also has an ethical significance. This should not come as a surprise-after all, even the passage in Philippians, which is the original source of the kenotic tradition, presents some immediate ethical implications. In fact, with his description of the incarnation of Christ as a 'withdrawal', the author of the letter to the Philippians clearly intended to call for an imitation of Christ: Christians are required to follow Christ's example by sacrificing themselves. However, the sacrifice to which Christians are called is different from traditional sacrifice (the suppression of something for the sake of something else). Here, the sacrifice of Christ is assumed to be a paradigm for a sacrifice conceived as a withdrawal or a 'making room' for others. When Hegel claims that Christ should be the normative paradigm for the church (qua community of Christ's followers), ${ }^{\mathrm{xxxiv}}$ he is not simply retaining some elements of the well-established tradition of the Imitatio Christi. In fact, Hegel's reception of this tradition appears more meaningful once it is considered in light of the kenotic sacrifice. In Hegel's view, the incarnation of Christ represents a turning point in the history of spirit, as Christ becomes the exemplar of the kenotic sacrifice, on which we humans can model our normativity. One of the novelties of the Christian church consists in its willingness to perform a twofold withdrawal: the first, in which each individual gives up her subjectivity (previously perceived as absolute objectivity) to establish the intersubjectivity of the community; ${ }^{\mathrm{xxx}}$ and the second, in which the community gives up its inner spirituality (the traditional spiritual component of a religious community) to engage with the world. As Hodgson comments, 'Hegel traces a movement from heart to church to ethical life, a movement that points to freedom as the telos of world history. The freedom of the basileia community passes into social and political freedom'. xxxvi 
There is a strict interrelation between the affirmation of Christianity, with its central image of the incarnation as the kenotic sacrifice of Christ, and the rise of the age of modern freedoms. The immortal Greek gods symbolise an idea of freedom as being untouched by human frailty and weakness. The angry and jealous God of the Old Testament, then, that absolute lawgiver and judge who looked at the world 'from the God's eye point of view', represents the negation of freedom for the sake of a 'legal morality'. Finally, the Christian God, who accepts human finiteness until death and represents a model for the kenotic sacrifice, is cognate with modern freedom. Hegel is explicit in saying that it was through Christianity that the idea of freedom came into the world. ${ }^{\text {xxxvii }}$ Modern freedom does not consist in keeping distance from otherness, but rather, by a full acceptance of otherness, in a process that is realised through a withdrawal of one's personality (in Aufgeben seiner Persönlichkeit). This is what love consists in: 'a self-conscious activity, the supreme surrender [of oneself] in the other'. ${ }^{\text {xxviii }}$ As Hegel writes in the section of the 1827 Lectures entitled 'The Idea of Reconciliation and Its Appearance in a Single Individual', 'The other-being, the finitude, the weakness, the frailty [Gebrechlichhkeit] of human nature is not to do any harm to that divine unity which forms the substance of reconciliation. [...] the selfpositing and sublating of otherness is love or spirit' (LPR 453-454). ${ }^{\text {xxix }}$ Modern social and political freedoms are therefore associated with the idea of kenotic sacrifice that is represented by the incarnation of Christ, that is, with the renunciation of the God's eye point of view and the withdrawal of one's own personality, or point of view, to recognise other personalities and points of view.

It has been said that recognition is the organising principle of that 'realm of reason' in which the human normative and cultural world consists. Because the incarnation of Christ is the representation of the kenotic sacrifice, which in turns makes recognition possible, the rise of this idea (in the form of religious narrative) in that same realm of reason really is a turning point in the history of spirit, a turning point that hence sheds light on how metaphysics (conceived as that discipline concerned with the realm of reason) is to be interpreted. Therefore, the last section of this paper will be devoted to an examination of some of the consequences that the idea of God, as presented in Hegel's philosophy of religion, has for an idealist metaphysics. 


\section{Beyond the Split of Right and Left Hegelians: The Idea of God and Hegel's}

\section{Idealist Metaphysics}

Read as an idealist in a post-Kantian sense, Hegel may be seen as conceiving of metaphysics as the discipline in which reason is concerned with its own products. Hence, God, qua object of metaphysics, should be regarded as having an ideal existence. It follows that the status assigned to the idea of God might be indicative of the way in which an idealist should deal with objects of metaphysics generally. Moreover, the idea of God is not merely a product of reason among many others, as it plays a very peculiar role. Religious belief systems are, for Hegel, to be understood as non-conceptual presentations of a content that is conceptually presented in philosophy. Therefore, just as a proper understanding of Hegel's metaphysical view is relevant for appreciating his conception of the nature of religious experience and representation, so too his particular views about the incarnation of Christ and the kenotic sacrifice shed light on how his metaphysics is to be interpreted. In Hegel's own words, 'Philosophy is only explicating itself when it explicates religion, and when it explicates itself it is explicating religion' (LPR 78-79).

In Western thought, the picture of God has always been indicative of the knowledge aspired to in philosophy. For instance, the Aristotelian God, the immutable and fully actualised 'unmoved mover' ('thought thinking itself') was indicative of the goal of philosophy as a metaphysical immutable knowledge of an 'ultimate' reality. The mainstream tradition in Medieval and early modern philosophy does not substantially divert from that image of God, with the addition of the attribute of omniscience as a consequence of the introduction of a personalistic component (the Judeo-Christian omnipotent God). In the domain of epistemology, this image is connected with a conception of metaphysics as expressed by the phrase 'god's-eyeview', ${ }^{\mathrm{xl}}$

The image of God emerging from Hegel's account of Christianity briefly sketched in the previous section represents a challenge to the traditional view mentioned above. Hegel's emphasis on the figure of Christ, that is, God emptying itself of its divine attributes (such as omnipotence and omniscience) ${ }^{\mathrm{xli}}$ to become human (that is, historically and geographically located), suggests a conception of metaphysical knowledge different from traditional pre-Kantian metaphysics. The organising principle of an idealist metaphysics is the reciprocal recognition of different finite 
points of view. As the image of the Aristotelian immutable god was consistent with an account of metaphysics as knowledge of an 'ultimate' reality (what is there 'anyway'), Hegel's image of the kenotic Christian God (who renounces the 'god'seye-view') is consistent with an account of metaphysics as knowledge of 'ideal' objects dependent on human recognition.

Hegel's turn to Christianity and his emphasis on Christ's incarnation and sacrifice can be regarded as evidence for the increasing integration of Kantian elements into his metaphysics as well as being indicative of his endorsement of the peculiarly kenotic dimension of sacrifice. This endorsement is clear from the last few lines of Hegel's passage on the interiorised sacrifice quoted in the first section. After having said that 'ethical life is the most genuine cultus' but that 'consciousness of the true, of the divine, of God, must be directly bound up with it', Hegel adds: 'To this extent philosophy [too] is a continual cultus. [...] It is part of knowing the true that one should dismiss one's subjectivity' (LPR 194). This quotation seems to suggest that a fundamental component of metaphysical knowledge (idealistically conceived) consists in the dismissal of subjectivity. As already mentioned, subjectivity is nothing else but the false presumption of objectivity ('pure certitude of itself in contrast with the truth', PR §25), and this is precisely what has to be given up to gain real metaphysical knowledge.

The idea of God, as it is presented in Hegel's philosophy of religion, is the image of an idealistic standpoint in the domain of epistemology and metaphysics. It also has a peculiar normative value, as it appears from Hegel's appeal to the tradition of Imitatio Christi, and therefore it has an ethical significance: human subjects are required to imitate Christ in his sacrifice / withdrawal. Does this mean that the function of the idea of God in Hegel's philosophy is merely that of an epistemological and ethical metaphor?

This question is anything but new, as it was at the root of the split that developed between the so-called 'right Hegelians' and 'left Hegelians' after Hegel's death. As is known, the right Hegelians, representing the theist faction of Hegel's followers, considered Hegel a realist concerning God. This position was clearly mistaken, as Hegel was an idealist concerning God. Thus, the left Hegelians (such as Strauss and Feuerbach) were correct in their opposition to the theistic reading of Hegel. However, they were wrong in turning Hegel's thought into a 'humanist' critique of theism. 
Hegel's approach to religion, they claimed, should be interpreted as implying a conception of God as a human projection. Consider the case of Feuerbach, with his anthropological reading of God as a human 'creation', that is, as a mere projection of human desires. This position represents a serious regression into pre-Kantian metaphysical realism, as it assumes that it is possible to distinguish, in the realm of reason, what is there 'anyway' from what is a 'mere' projection. However, in light of Kant's 'strong transcendental idealism', which was developed more fully by Hegel, this distinction simply does not make sense because everything, in the realm of reason, is based on recognition. In Hegel's view, nothing is there 'anyway' in that realm, but everything —including the idea of God—is dependent upon the human activity of recognition. Considered in this way, the idea of God can be said to be a human 'creation'-but only in the same way in which it is possible to say that human rights, or human beings (considered as free and rational beings) are human 'creations'.

At this point, one might object that, beyond the crude anthropological reading, Feuerbach and the other left Hegelians were, after all, correct, as there is a sense in which Hegel is an atheist insofar as he does not attribute to God any existence external to reason. In this reading, for instance, the claim that the kenotic sacrifice is the model for expounding what recognition entails should be regarded as meaning that it is merely a symbolic representation, or even a metaphor, of a content that is better and more clearly presented in conceptual terms within philosophy. This interpretation can be applied to all religious notions and beliefs. However, this account represents, in my view, a subtler, but still serious, misunderstanding of Hegel's approach to the idea of God. Again, interpreting Hegel as a post-Kantian philosopher can shed light on this misunderstanding.

Kant's account of the categorical imperative implies a repeated insistence that moral commands should be listened to as if they were spoken by the voice of God. That is, the categorical imperative should be regarded as a duty toward God. ${ }^{\text {xlii }}$ Kant's insistence represents an attempt to solve the paradox that, according to Terry Pinkard, is implied in the Kantian idea of self-legislation (the idea that one has to be bound by laws of which one is also the author). ${ }^{x i i i}$ Feuerbach and the other left Hegelians considered the distribution of the activity of the constitution of norms over the species to be a better solution to the Kantian paradox. Some recent interpretations of Hegel 
seem to suggest that Hegel too should be regarded as employing a similar strategy. ${ }^{\text {xiv }}$ From this point of view, Hegel's recognitive approach should be taken as meaning that values and norms are merely cultural and social reflections. In respect to religion, the claim that the idea of God has no existence external to reason should be taken as meaning that it exclusively has a social function. This interpretation, I think, runs the risk of turning Hegel's account of the idea of God into a kind of instrumentalism or expressivism (although a socially-based rather than individualistic form of expressivism), with the concept of God conceived as a merely useful instrument whose worth is measured by how effective it is in explaining social phenomena.

Regarding norms and values in general (but including religious representations), Paul Redding has recently suggested that from an Hegelian point of view they cannot be regarded 'as merely the cultural reflections of a particular finite society' and that their representations 'are afforded a type of necessity' that 'is part of the status they have as norms'. xlv Here, I want to focus more closely on the status that should be assigned to the idea of God from the point of view of the Hegelian approach and on the implications that this idea has in the domain of metaphysics.

The source of the mentioned misunderstanding resides, I think, in the confusion between 'God' and 'the idea of God'. It has already been stated that Hegel considers God qua object of the philosophy of religion. The object of his analysis is not God and its existence external to reason; Hegel is neither committed to affirming its independent existence (right Hegelians) nor its non-existence (left Hegelians) simply because it would not make any sense to claim anything about the independent existence of an object of reason, which for its very nature is dependent on human reason. Hegel's 'infamous' defence of the ontological argument for the existence of God should, I suggest, be considered in this light. Kant's confutation is, Hegel claims,

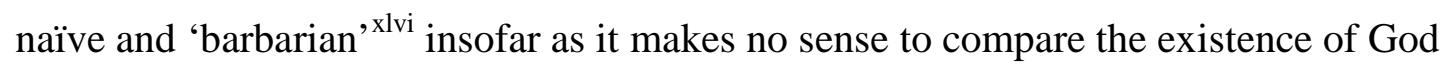
(an object of reason) with the existence of natural objects, as they belong to different domains. Hegel's methodological approach, which Redding has labelled 'cognitive contextualism', xlvii allows the consideration of God not qua object of perception (Gegenstand), but qua idea in a Kantian sense - that is, as playing a crucial regulative role in the realm of reason. Regarding the idea of God as having no existence external to reason makes Hegel neither a theist nor an atheist concerning God (at least not in the traditional sense). ${ }^{x l i i i}$ However, regarding the idea of God as having no existence 
external to reason does not make God a merely fictional character, it rather makes God's metaphysical reality (its existence as an object of reason) conditional upon the mutual recognition between individuals. Thus, religion can be viewed as something clearly personal, but not exclusively subjective.

Therefore, I think it is a mistake to regard the idea of God as playing a mere social function in Hegel's account. To claim that the idea of God plays a crucial normative role in the realm of reason (to which it belongs), means that its content is significant for the lives of individuals (subjective spirits) insofar as it is regulative of their interactions and constitutive of their identities not only at the social, but also at the psychological and existential level. What is the peculiar content of the Christian idea of God? ${ }^{x \text { lix }}$ Hegel clearly takes the incarnation of Christ to be at the heart of Christianity, and the incarnation expresses the kenotic sacrifice of God. The kenotic sacrifice is the expression of a spirit that advances only insofar as it is willing to withdraw and make room for the other. As such, the Christian idea of God represents not only a normative idea in ethics (the 'imitation of Christ' mentioned above); it also has a regulative impact on philosophy itself insofar as it enhances a perspectival standpoint. Kant suggested considering the idea of God as a representation of the systematic unity of knowledge toward which we aspire-as if there were a single unified body of knowledge. To posit the idea of a God who, insofar as he accepts becoming human (i.e., historically located), is affected by the same partiality in perspective that we as humans suffer, is to undermine the traditional idea of (metaphysical) knowledge as 'the omnicomprehensive point of view', and to replace it with an idea of knowledge as an expression of all different (and even contrasting) points of view. ${ }^{1}$

Furthermore, Hegel stresses that Christ became the 'perfect [vollkommenen] man' because 'He suffered, sacrificed himself, negated his naturalness and thereby elevated himself above it' Hegel also emphasises that the renunciation of his 'naturalness' is something 'which is to come to pass in the subject', that is, in us as humans. In the philosophical register, this call might be regarded as an invitation to renounce the natural or naturalistic domain and to focus on the recognitively-based structure of norms and values.

I have shown that Hegel's philosophy of religion is compatible with a post-Kantian interpretation of his thought. Hegel's account of metaphysics is strictly interdependent 
with his idea of God (the source of norms). The idea of God (and the norms represented by it) is personal and subject to finitude, but it is not thereby exclusively subjective, and it does not relinquish its universality. In Hegel's view, psychological subjects ('subjective spirits') are embodied within forms of finite life that are shaped by normative and action-guiding narratives that carry strong affective charges. These narratives constitute religion. Conceived in this way, religious narratives and notions regulate the interaction of subjects, and they contribute to those core commitments that are constitutive of moral identity. In this context, the notion of kenotic sacrifice plays a hidden and yet fundamental role. Expressed by the incarnation and the death of Christ, the kenotic sacrifice significantly shapes both modern moral identity and modern post-Kantian metaphysics. Sacrifice as withdrawal (giving up something of one's own identity to make room for other points of view and perspectives) is significant not only because of its capacity to express a philosophical concept (mutual recognition) in an emotionally affecting and motivating representation, it also necessitates a historically-located will to realise and improve a (potentially universal) recognitively-based structure of norms and values. This will has a significant impact on the development of a post-Kantian and idealist philosophy.

\section{References}

G. W. F. Hegel:

$E L=$ Encyclopaedia Logic, trans. T. F. Geraets et al. (Indianapolis: Hackett, 1991);

LHP $=$ Lectures on the History of Philosophy 1825-1826, Vol. III: Medieval and Modern Philosophy. Trans. Robert F. Brown. Oxford: Oxford University Press, 2009

LPR $=$ Lectures on the Philosophy of Religion. The Lectures of 1827, ed. P. C. Hodgson, trans. R. F. Brown et al. (Berkeley: University of California Press, 1988)

$L P R 1=$ Lectures on the Philosophy of Religion, vol. 1: Introduction and the Concept of Religion, ed. P. C. Hodgson, trans. R. F. Brown et al. (Berkeley: University of California Press, 1984)

PH = Philosophy of History, trans. J. Sibree, Kitchener: Batoche Books, 2001 
$P R=$ Philosophy of Right, Translated by S.W Dyde Batoche Books, Kitchener, Ontario, 2001

PS = Phenomenology of Spirit, trans. A. V. Miller (Oxford: Oxford University Press, 1971)

$P M=$ Philosophy of Mind, trans. W. Wallace \& A. V. Miller, revisions M. J. Inwood (Oxford: Clarendon Press, 2007)

EPW = Enzyklopädie der philosophichen Wissenschaften (Hamburg: Meiner Verlag, 1991).

$W=$ Werke in zwanzig Bänden, eds. E. Moldenhauer \& K. M. Michel (Frankfurt am Main: Suhrkamp Verlag, 1970).

Altizer, T. J. J. (1967), The Gospel of Christian Atheism. London: Collins

Bataille, G. (1955), 'Hegel, la Mort et le Sacrifice', Deucalion, 5: 21-43. Trans. J. Strauss, 'Hegel, Death and Sacrifice', Yale French Studies, 78 (1990): 9-28.

Bataille, G. (1993), The Accursed Share, trans. R. Hurley. New York: Zone Books

Brandom, R. B. (2002), Tales of the Mighty Dead. Cambridge, MA: Harvard University Press.

Derrida, J. (1978), Writing and Difference. London: Routledge \& Kegan Paul.

Gardner, S. (1999), Kant and the "Critique of Pure Reason”. London: Routledge.

Hodgson, P. C. (2005), Hegel and Christian Theology: A Reading of the Lectures on the Philosophy of Religion. Oxford - New York: Oxford University Press.

Houlgate, S. (2004), 'Religion, Morality and Forgiveness in Hegel's Philosophy', in W. Desmond, E.-O. Onnasch and P. Cruysberghs (eds.) Philosophy and Religion in German Idealism. Dordrecht: Springer.

Jaeschke, W. (1990), Reason in Religion: The Foundations of Hegel's Philosophy of Religion, trans. J. M. Stewart and P. C. Hodgson. Berkeley: University of California Press.

Jüngel, E. (1983), God as the Mystery of the World: On the Foundation of the 
Theology of the Crucified One in the Dispute between Theism and Atheism, trans.

D. L. Guder. Grand Rapids, MI: Eerdmans.

Kant, I. (1960), Religion Within the Limits of Reason Alone, tr. T. M. Greene and H. H. Hudson. New York: Harper \& Row.

Kant, I. (1992), Lectures on Logic. Cambridge: Cambridge University Press.

Kline, G. (1964), 'Some Recent Reinterpretations of Hegel's Philosophy', The Monist, 4 no. $8: 34-75$.

Kojève, A. (1969), Introduction to the Reading of Hegel, New York: Basic Books.

Lanzetta, B. J. (1992), 'Three Categories of Nothingness in Eckhart', The Journal of Religion, 72, No. 2: 248-268.

Moltmann, J. (1985), God in Creation: A New Theology of Creation and the Spirit of God, trans. M. Kohl. San Francisco: Harper \& Row.

Nuzzo, A. (2009), 'Vagueness and Meaning Variance in Hegel's Logic', in A. Nuzzo (ed.) Hegel and the Analytic Tradition. London and New York: Continuum.

O'Regan, C. (1994), The Heterodox Hegel. Albany: State University of New York Press.

Pagano, M. (1992), Hegel: la Religione e l'Ermeneutica del Concetto. Napoli: ESI.

Pinkard, T. (1994), Hegel's Phenomenology: the Sociality of Reason. Cambridge: Cambridge University Press.

Pinkard, T. (2002), German Philosophy 1760-1860: The Legacy of Idealism, Cambridge, Cambridge University Press

Pippin, R. B. (1989), Hegel's Idealism. Cambridge: Cambridge University Press.

Pippin, R. B. (1991), Modernism as a Philosophical Problem. Cambridge: Cambridge University Press, $2^{\text {nd }}$ ed. 1999.

Pippin, R. B. (2000), 'What is the Question for which Hegel's Theory of Recognition is the Answer?', European Journal of Philosophy, 8, no. 2: 155-72.

Pippin, R. B. (2008), Hegel's Practical Philosophy: Rational Agency and Ethical Life. Cambridge: Cambridge University Press. 
Polkinghorne, J. ed. (2001), The Work of Love: Creation as Kenosis. Grand Rapids, MI: Eerdmans.

Redding, P. (1996), Hegel's Hermeneutics. Ithaca: Cornell University Press.

Redding, P. (2007a), 'Hegel, Idealism and God: Philosophy as the Self-Correcting Appropriation of the Norms of Life and Thought'. Cosmos and History: The Journal of Natural and Social Philosophy, 3., nos. 2-3: 16-31.

Redding, P. (2007b), 'Hegel, Fichte and the Pragmatic Context of Moral Judgement', in E. Hammer (ed.) German Idealism: Contemporary Perspectives. London and New York: Routledge.

Redding, P. (2007c), Analytic Philosophy and the Return of Hegelian Thought. Cambridge: Cambridge University Press.

Redding, P. (2009), Continental Idealism: Leibniz to Nietzsche. London and New York: Routledge.

Weeks, A. (1991), Boehme: An Intellectual Biography of the Seventeenth-Century Philosopher and Mystic. New York: State University of New York Press.

Williams, R. R. (1997), Hegel's Ethics of Recognition. Berkeley: University of California Press.

Yerkes, J. (1978), The Christology of Hegel. Missoula, MT: Scholars Press. 
' See Pippin 1989 and Pippin 1991. See also Pinkard 1994 and Pinkard 2002. Another significant revival of Hegel studies is represented, from the perspective of analytic philosophy, by the work of Robert Brandom and John McDowell.

ii Hegel describes pre-Kantian metaphysics as a 'naive way of proceeding' (EL § 26: 65; W 8: 93) because it 'regarded the thought-determinations' it uses 'as the fundamental determination of things' (EL § 28). (I am grateful to Damion Buterin for calling these quotes to my attention). In this paper, I will use the expression 'Post-Kantian interpretation' in a this broad sense, that is, as a catch-all phrase for all those interpretative approaches that see Hegel's philosophy as representing an extension of Kant's critical philosophy (thus including such an interpretative standpoint as that of Paul Redding, which, in a strict sense, cannot be included in the Pippin-Pinkard school of thought).

iii See, for example, the Preface to the first edition of the Critique of Pure Reason (Axx).

iv Gardner 1999: 22, 30-33.

${ }^{\vee}$ Redding 2009: 2, 47, 62.

${ }^{\text {vi }}$ Kant 1992: 590.

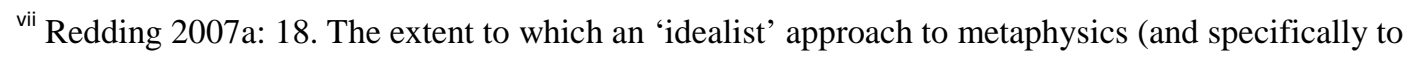
God) is also a 'non-realist' approach to God is something that I will consider in the final section of the paper.

viii Cf. Redding 2009: 150f.

${ }^{\text {ix }}$ Redding 2007a: 27. An application of the notion of recognition to Hegel's metaphysics was already suggested in Redding 1996: ch. 7.

${ }^{\mathrm{x}}$ Cf. Williams 1997.

${ }^{x i}$ To date, interpretations of Hegel's writings on theology and religion have assumed that his systematic thought concerning 'spirit' is metaphysically realist. While some interpreters, such as Jaeschke (1990) and Hodgson (2005), stress the rationalist dimension of Hegel's view on religion, and other interpreters, such as O'Regan (1994), stress the mystical features of Hegel's thought, the basic shared assumption is that Hegel was essentially a realist about God.

xii Bataille 1955/1990.

xiii Cf. Hodgson 2005: 39

${ }^{\text {xiv }}$ In The Accursed Share, Bataille refers to the rite of potlatch, practiced among indigenous peoples of the Pacific Northwest Coast, in which the participants destroy or burn goods as an example of pure 
sacrificial expenditure. However, Bataille himself recognises that the overall goal of the ritual is a manifestation of power by a family or a tribe, so that he eventually admits that 'the ideal would be that a potlatch could not be repaid' (Bataille 1993: 70).

${ }^{x v}$ For Hegel 'subjectivity' and 'objectivity' are relative rather than absolute terms: 'It is ordinarily supposed that subjective and objective are blank opposites; but this is not the case. Rather they pass into one another, for they are not abstract aspects like positive and negative, but have already a concrete significance' (PR §26a).

${ }^{x v i}$ In the Philosophy of Right, Hegel refers to this notion, or phase, of subjectivity as 'particularity of will, as caprice with its accidental content of pleasurable ends' (PR §25).

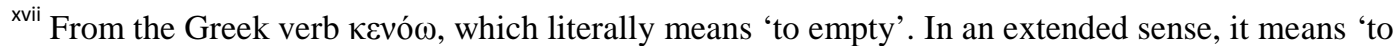
make ineffective'.

xviii Literally, 'retraction'. Tsimtsum is a term used in the Kabbalistic teaching of Isaac Luria, a Jewish mystic of the sixteenth century. Tsimtsum is the first act of God: it is the retraction of his light from a certain space so as to reduce its intensity and allow created beings to exist.

${ }^{x i x}$ German theologian Jürgen Moltmann, explaining the kenotic view of creation, writes the following: 'God "withdraws himself from himself to himself" to make creation possible. His creative activity outwards is preceded by this humble divine self-restriction. In this sense God's self-humiliation does not begin merely with creation, inasmuch as God commits himself to this world: it begins beforehand, and is the presupposition that makes creation possible. God's creative love is grounded in his humble, self-humiliating love. This self-restricting love is the beginning of that self-emptying of God that Philippians 2 sees as the divine mystery of the Messiah. Even to create heaven and earth, God emptied himself of all his all-plenishing omnipotence, and as Creator took upon himself the form of a servant'. (Moltmann 1985: 88). For an introduction to the employment of the notion of kenosis in connection with God's creation, see Polkinghorne 2001.

${ }^{x x}$ One of Eckhart's most peculiar doctrines concerns the notion of Abgeschiedenheit. This term, usually translated as 'disinterestedness' or 'detachment' in English, effectively refers to the kenotic emptying of the self as a result of the imitation of Christ: 'In Eckhart is found a profound mystical understanding of this twofold kenosis: the one occurs in the bullitio, the "boiling over," of the Trinity from the nothingness of the desert and in which the Father pours the totality of his divinity into the Son; the other occurs in the ebullitio, "flowing out," of the Trinity towards creation, and the Son's selfemptying of his divinity for the sake of the world'. Lanzetta 1992: 260.

${ }^{\times x i}$ Cf. Weeks 1991: 2-3.

${ }^{x \times i i}$ Eckhart remained consistent, in this respect, with Thomas Aquinas' conception of a perfect and immutable God, which basically replicated the Aristotelian conception of God as 'unmoved mover'. 
xxiii Ibid. What is this referring to?

xxiv O'Reagan 1994: 216-231. For a theological account of Hegel's reception of Böhme's notion of kenosis, see Altizer 1967. Introducing the section on kenosis, Altizer writes: 'While this radical expression of Christian mysticism was driven underground by the ecclesiastical authorities of the Church, it continued to exist in a subterranean form, finally surfacing in Jakob Böhme and his circle, who provided the germinal source for the one thinker who created a conceptual portrait of the incarnate or kenotic movement of God: Hegel' (Altizer 1967: 62-63).

${ }^{x \times v}$ Classical German Idealism, from Kant to Hegel, might be considered as transforming the Platonic world of ideas, in which the existence of objects is to be regarded as analogous to the existence of natural objects, into a realm of reason, in which objects are normative and regulative ideas, and hence, dependent upon human cognitive activity. Cf. Redding 2009: 63-69.

${ }^{x x v i}$ Cf. Pippin 2000: 155-72.

xxvii 'Self-consciousness exists in and for itself when, and by the fact that, it so exists for another; that is, exists only in being acknowledged' (PS 177-178).

xxviii 'This does not make selves unreal or fictional, it simply makes their reality, unlike that of nature, conditional upon their recognition by others' (Redding 2007a: 27-28).

${ }^{x x i x}$ Redding 2007a: 24.

${ }^{x x x}$ 'For Hegel, "concrete" means "many-sided, adequately related, complexly mediated" (we may call this "concrete $[\mathrm{H}]$ ") while "abstract" means "on-sided, inadequately related, relatively unmediated" (abstract $[\mathrm{H}]$ ). A concept or universal can quite sensibly be characterized as concrete $[\mathrm{H}]$, and at the same time, without paradox, as abstract [E] [the empiricist sense]. Sense particulars, or "sensuous immediacy," will necessarily be abstract $[\mathrm{H}]$ and at the same time, unparadoxically, concrete [E]' (Kline 1964: 41).

${ }^{x \times x i}$ 'The Greek gods must not be regarded as more human than the Christian God. Christ is much more a Man: he lives, dies_-suffers death on the cross—which is infinitely more human than the humanity of the Greek Idea of the Beautiful' (PH 267).

${ }^{\text {xxxii }}$ Analogously, 'Hegel's philosophy of nature is just that, a philosophy of nature, not a competing scientific account of natural phenomena or a philosophy of science.' See Pippin 2008: 49.

xxxiii Eberhard Jüngel (1983) credits Hegel with a deeply profound (but, according to Jüngel, misguided) understanding of the Trinity, which Jüngel uses to develop his own assertion that 'God's being is in becoming'. However, Jüngel understands Hegel in a traditionally metaphysical way. Conversely, once Hegel is approached from the point of view of the 'post-Kantian' reading, the idea of God as a 'being in becoming' can be regarded as Hegel's 'original account'. 
${ }^{\text {xxxiv }}$ LHP 3: 5. Cf. also Yerkes 1978: 136-137. Yerkes has the merit of having called attention to the mentioned Hegelian passages. He does not, however, make the connection between kenosis and the tradition of Imitatio Christi.

${ }^{x x x v}$ Cf. PH 345.

${ }^{\text {xxxi }}$ Hodgson 2005: 281. Some lines below, Hodgson adds that for Hegel 'religion, like art, is mostly a thing of the past'. This comment does not do justice to the complexity of the relation between philosophy and religion in Hegel's thought.

xxxvii 'It was through Christianity that this Idea came into the world. According to Christianity, the individual as such has an infinite value as the object and aim of divine love, destined as mind to live in absolute relationship with God himself, and have God's mind dwelling in him: i.e. man is implicitly destined to supreme freedom' (PM 101). Cf. Pippin 2008: 134-135.

${ }^{\text {xxxviii } L P R ~ 3: ~ 27 f f . ~}$

${ }^{\text {xxxix }}$ This dynamic has been beautifully illustrated by Stephen Houlgate: '[...] divinity consists not in superhuman majesty and power, but in living a finite human life of love. In Christ, therefore, we see that human "frailty" (Gebrechlichhkeit) does not cut us from God [...] but is precisely what enables us to manifest divine love must fully'. (Houlgate 2004: 93).

${ }^{\mathrm{x} l}$ Redding suggests that the 'paganism' of the young Hegel (and Schelling) might be connected with a critique directed at traditional metaphysical knowledge. Cf. Redding 2007a: 24.

${ }^{x l i}$ Redding 2007c: 228.

xlii 'Since all religion consists in this, that in all our duties we look upon God as the lawgiver universally to be honored'. Kant 1960: 95.

xliii Cf. Pinkard 2002: 227. Pinkard reads the entire history of German Idealism as a history of attempts at responding to this paradox and finding a solution to it.

${ }^{x \text { liv }}$ Brandom seems to suggest such an instrumentalist view when he insists that 'For Hegel all transcendental constitution is social institution' (Brandom 2002: 216).

${ }^{\mathrm{x} l v}$ Redding 2007a: 29.

${ }^{\text {xlvi }}$ EPW 51. Kant has argued that both the existence and the non-existence of God cannot be rationally demonstrated. From the point of view of Hegel, Kant's thought plays the role of a kind of negative theology - a theology that attempts to gain and express knowledge of God by describing what God is not - but this is not a satisfactory solution for Hegel.

xlvii Redding 2007: 19-20 
xviii In other words, the existence of God beyond the realm of reason might be regarded as a faith belief, but it is a false problem from the point of view of philosophy.

${ }^{x l i x}$ I believe Angelica Nuzzo provides an account along these lines when she contrasts the language of the ancient gods (the language of 'concept') with the language of speculative philosophy (the language of 'dialectic'). She writes: 'Truth is not gained by an improbably flight in the abstractness of thinking (where the "immortal gods" whose language we may imagine to speak are not the gods of truth but of mere fantasy). Truth is reached instead by recognizing and consequently rectifying (not revoking) its "incarnation" in ordinary language. To put it in Hegel's figurative way, in speculative philosophy truth speaks the language of an incarnated god. The language of dialectic is not the incomprehensible language of fantastic gods (or of past metaphysics) but the language of "actual spirit" (wirklicher Geist)'. (Nuzzo 2009: 65-66).

'Paul Redding points out that the integration of Christianity in Hegel's metaphysics is also connected with Hegel's opposition to the scepticism that is associated with the discovery that the norms to which we hold are finite: 'Because even God is affected by such finitude [...], Christian mythology gives expression to a stance which undermines the normative assumptions upon which scepticism makes sense' (Redding 2007a: 30). This emphasis on perspectivism might lead to the consideration of Hegel as a 'hermeneutic theorist' ante litteram, as suggested from different interpretative standpoints by Pagano 1992 and Redding 1996.

${ }^{\text {li }}$ LHP 3:5. Yerkes underlines the importance of this passage, but seems to interpret it in a realist rather than idealist way. Cf. Yerkes 1978: 274. 